\title{
Artikel
}

\section{Langlopende letselschadezaken: wat zijn de belangrijkste kenmerken?}

Dr. mr. R. Rijnhout, D.W. van Maurik LLB, mr. dr. E.G.D van Dongen en prof. mr. I. Giessen*

\section{Inleiding}

In september 2020 werd het onderzoek van het Utrecht Centre for Accountability and Liability Law (Ucall) van de Universiteit Utrecht naar langlopende letselschadezaken openbaar. ${ }^{1}$ Het onderzoek werd uitgevoerd in opdracht van De Letselschade Raad op verzoek van het ministerie van Justitie en Veiligheid. Het doel van het onderzoek was om inzichtelijk te maken wat de belangrijkste kenmerken zijn van dossiers die langlopend zijn en of er verbanden bestaan tussen die kenmerken. Langlopende letselschadezaken zijn langlopend wanneer een dossier niet binnen twee jaar na de schademelding is afgewikkeld. Daarmee wordt aangesloten bij de twee-

Dr. mr. R. Rijnhout LLM is als Universitair hoofddocent verbonden aan Ucall en het onderzoekscluster Empirical legal research into institutions for conflict resolution, en was projectleider van dit onderzoek. D.W. van Maurik LLB is student-assistent bij Utrecht Centre for Accountability and Liability Law (Ucall) en heeft tevens als onderzoeksstudent een bijdrage geleverd aan de uitvoering van het onderzoek. Mr. dr. E.G.D. van Dongen LLM is als Universitair docent verbonden aan Ucall. Prof. mr. I. Giesen is als hoogleraar burgerlijk recht verbonden aan Ucal.

1. R. Rijnhout, E.G.D. van Dongen, D.W. van Maurik \& I. Giesen, Langlopende letselschadezaken. Een empirisch-juridisch onderzoek naar kenmerken van letselschadezaken die niet binnen twee jaar zijn afgesloten, Den Haag: Boom juridisch 2020. Het onderzoeksrapport is open access te raadplegen via de website van De Letselschade Raad: https:// deletselschaderaad.nl/wp-content/uploads/Langlopende-

letselschadezaken-rapport.pdf. In het onderstaande wordt verwezen naar de paginanummers van de onlineversie die open access beschikbaar is. jaarstermijn die in de Gedragscode Behandeling Letselschade wordt gehanteerd. ${ }^{2}$

Het belang om de looptijd van het letselschadetraject te beperken, is voor alle partijen groot. Uit onderzoek blijkt dat de afwikkeling van letselschadedossiers belastend kan zijn voor slachtoffers, waardoor slachtoffers die een claim instellen minder vlot herstellen dan slachtoffers die dat niet doen. ${ }^{3}$ De voortvarendheid waarmee belangenbehartigers handelen is eveneens belangrijk voor slachtoffers. Ook voor aansprakelijkheidsverzekeraars is het belangrijk om letselschadedossiers voortvarend en naar tevredenheid voor beide partijen af te wikkelen, omdat daarmee de schadelast en de afwikkelingsinvestering laag gehouden kunnen worden. ${ }^{4}$ Het doel van deze bijdrage in om een samenvatting te geven van de belangrijkste bevindingen van het onderzoek. Een uitwerking van de bevindingen is terug te vinden in het rapport. ${ }^{5}$

Dit artikel is als volgt opgebouwd. In paragraaf 2 worden de opzet en de methoden van het onderzoek toegelicht. In paragraaf 3 worden enkele algemene kenmerken geschetst. In paragraaf 4 worden de belangrijkste resultaten van het onderzoek gepresenteerd. Dat doen wij aan de hand van een aantal overkoepelende thema's. In paragraaf 4 wordt een algemene conclusie

2. De Letselschade Raad, Gedragscode Behandeling Letselschade 2012, Den Haag: De Letselschade Raad 2012, te vinden via https:// deletselschaderaad.nl/downloads/GBL-20121.pdf.

3. N.A. Elbers \& A.J. Akkermans, 'Epidemiologische inzichten in het effect van letselschadeafwikkeling op herstel en de zoektocht naar mogelijkheden tot verbetering', TVP 2013, p. 33-39.

4. N.A. Elbers, K.A.P.C. van Wees \& A.J. Akkermans, "'M Hij schreef dat hij contact op zou nemen zodra hij de tegenpartij had gesproken": letselschadeslachtoffers over hun belangenbehartiger. Empirisch onderzoek brengt vijf belangrijke factoren voor waardering belangenbehartiger aan het licht', TVP 2012, p. 112.

5. Delen van deze bijdrage zijn letterlijke weergaven van de tekst in het rapport. 
gedeeld, waarna achtereenvolgens wordt stilgestaan bij: omstandigheden die samenhangen met de materieelrechtelijke beoordeling van een vordering centraal (paragraaf 5) omstandigheden die betrekking hebben op het afwikkelingsproces (paragraaf 6) en omstandigheden die samenhangen met het handelen van partijen (paragraaf 7 ). In paragraaf 8 wordt afgesloten met enkele overkoepelende reflecties.

\section{Opzet van het onderzoek}

Om een antwoord te kunnen geven op de vraag wat de belangrijkste kenmerken van langlopende letselschadedossiers zijn en welke verbanden te vinden zijn tussen die kenmerken, is gebruikgemaakt van een vijftal methoden:

- een literatuurstudie die als input dient voor het dossieronderzoek en het vragenlijstonderzoek;

- hen grootschalig dossieronderzoek bij aansprakelijkheidsverzekeraars;

- Het dossieronderzoek is uitgevoerd door QConsult Insurance (toen: QCPP) in opdracht van de Universiteit Utrecht. Onderzoekers van de universiteit hebben de checklist opgesteld en hebben tevens twee dagen het onderzoek bijgewoond.

- een omvangrijk vragenlijstonderzoek onder gedupeerden;

2 - enkele interviews met gedupeerden ter verificatie van de resultaten en/of doorvragen op vraagpunten;

- een focusgroep (zowel schriftelijk als online) met letselschadeprofessionals ter verificatie van de resultaten en/of doorvragen op vraagpunten.

Om tot een steekproef te komen die de werkelijkheid zo goed mogelijk benadert, heeft de steekproeftrekking plaatsgevonden via aansprakelijkheidsverzekeraars. ${ }^{6}$ Negentien aansprakelijkheidsverzekeraars zijn benaderd. Er is een spreiding aangebracht, waarbij gelet is op: klein/groot, regionaal/landelijk, oud/jong, wel/niet opgenomen in het Register Letselschade. Dertien aansprakelijkheidsverzekeraars waren bereid om mee te doen. Op verzoek is het Verbond van Verzekeraar nagegaan welk marktaandeel deze dertien verzekeraars vertegenwoordigen. Op basis van data bekend bij het Centrum voor Verzekeringsstatistiek (CVS) wordt duidelijk dat deze verzekeraars gezamenlijk een marktaandeel hebben in Nederland van $67 \%$.

$\mathrm{Om}$ in contact te komen met de gedupeerden hebben de onderzoekers een aselecte steekproef getrokken uit nietherleidbare dossierlijsten van langlopende letselschadedossiers die op dat moment in behandeling waren bij de dertien aansprakelijkheidsverzekeraars in Nederland. De dossiers in dit onderzoek betroffen drie verschil- lende soorten aansprakelijkheidsverzekeringen: wettelijke aansprakelijkheid van houders van motorrijtuigen (WAM), aansprakelijkheid van particulieren (AVP) en aansprakelijkheid van bedrijven (AVB). Naast de vereisten dat het moest gaan om WAM-, AVP- of AVB-zaken en dat het dossier langlopend moest zijn, moesten de dossiers van waaruit een steekproef werd getrokken ook aan een aantal andere criteria voldoen. Zo moest de aansprakelijkheid (gedeeltelijk) erkend zijn en moest de dekking vaststaan, ${ }^{7}$ mochten het geen dossiers zijn waarin vergoeding voor overlijdensschade werd gevorderd, mochten het geen dossiers zijn die enkel over regres gaan en mochten het geen dossiers zijn waarin enkel (nog) een voorbehoud was gemaakt en voor het overige zijn afgewikkeld. De participerende aansprakelijkheidsverzekeraars mochten niet een verdere voorselectie maken van de dossiers. Er zijn ook geen aanwijzingen dat dit is gebeurd.

Om tot een representatief totaalaantal dossiers te komen, zijn de volgende aannames gedaan:

- Het gaat om 60.000 nieuwe letselschademeldingen per jaar.

- Circa $15 \%$ betreft een 0 -schade, de aansprakelijkheid wordt afgewezen of er vindt geen uitkering van schadebedragen plaats.

- Van de 51.000 resterende zaken wordt circa 90\% binnen twee jaar afgewikkeld.

- De aantallen dossiers instroom (nieuwe meldingen), in behandeling (lopend) en afgewikkeld is redelijk in balans.

- Circa 5100 letselschadezaken lopen langer dan twee jaar en dus is in die zaken de persoonlijke schade nog niet afgewikkeld.

Wij gaan uit van een verdeling van typen verzekering van: $90 \%$ WAM, 5\% AVP, 4\% AVB en 1\% medisch. Op basis van deze aannames kwamen Ucall en Q-Consult Insurance tot de volgende steekproef per schadegroep:

De steekproefaantallen zijn berekend met een statistische ondergrens van $90 \%$ betrouwbaarheid/10\% foutmarge. Met andere woorden, toetsing bij herhaling leidt in negen van de tien gevallen tot gelijke uitkomsten en de uitkomst wijkt maximaal $10 \%$ af van de werkelijke waarde van de populatie. Het totaalaandeel WAM $(90 \%)$ is hoog ten opzichte van de rest. Deze categorie is derhalve aangevuld tot honderd dossiers.

De respons was als volgt: In het onderzoek konden uiteindelijke 201 dossiers worden meegenomen. ${ }^{8}$ Hoewel de spreiding van deze dossiers over type verzekering (WAM, AVP, AVB) in lijn was met de bekende spreiding, was het niet mogelijk om representatieve uitspraken per verzekering te doen, omdat de ondergrens
6. Een open oproep of de sneeuwbalmethode had ons minder mogelijkheden geboden om een zo goed mogelijk beeld van de werkelijkheid te krijgen. Door een combinatie van methode en dossier- en perceptieonderzoek verwachten wij geen kenmerken te hebben gemist.
7. Hiervoor is gekozen omdat er bij (aanvankelijke) erkenning/dekking een letselschadetraject wordt opgestart.

8. Rijnhout e.a. 2020, p. 51-52 voor meer informatie. 
Tabel 1 Steekproefomvang per type verzekering.

\begin{tabular}{llllll}
\hline Soort schade & Aandeel soort schade & $\begin{array}{l}\text { Verdeling dos- } \\
\text { siers }\end{array}$ & Steekproef & $\begin{array}{l}\text { Statistische } \\
\text { ondergrens } \\
90 / 10\end{array}$ & Aangevuld \\
\hline WAM & $90 \%$ & 4.680 & 100 & 67 & 33 \\
\hline AVP & $5 \%$ & 260 & 55 & 55 & 51 \\
\hline AVB & $4 \%$ & 208 & 51 & 173
\end{tabular}

\section{Tabel 2 Respons dossieronderzoek en vragenlijstonderzoek.}

Dossieronderzoek

Vragenlijst
223

262 voor AVP en AVB niet is gehaald. Daarom is alleen op het geheel geanalyseerd.

In totaal 195 gedupeerden hebben de vragenlijst ingevuld. Een omvangrijk deel van deze gedupeerden hebben aangegeven mee te willen werken aan een aanvullend interviem. Ten behoeve van een zo gevarieerd mogelijke steekproef zijn tien gedupeerden geselecteerd met een aselecte steekproef binnen alle respondenten die in het profiel pasten. Het eerste selectiecriterium was de periode waarin het ongeval was gebeurd. Zo is gezocht naar een zo breed mogelijke verdeling in de duur van het dossier. Ten tweede is geselecteerd op type letsel; er is gestreefd naar een spreiding op dit punt. Ten derde is geselecteerd op het type belangenbehartiger (advocaat, rechtsbijstandverzekering, schaderegelingsbureau en overige typen belangenbehartigers) en ten slotte is rekening gehouden met een gelijke verdeling tussen geslacht. ${ }^{9}$ Het aantal van tien interviews is te weinig om algemene uitspraken te doen; als wij in het onderstaande refereren aan de interviews, beogen wij dus geen algemene/representatieve uitspraken te doen. De zestien deelnemers aan de focusgroep zijn voorgedragen door de begeleidingscommissie. Vanwege de Covid-19 pandemie is een schriftelijke ronde gehouden en zijn vier onlinefocusgroepen gehouden met een zo divers mogelijke samenstelling.

Het onderzoek is onafhankelijk uitgevoerd en werd begeleid door een evenwichtig samengestelde begeleidingscommissie. ${ }^{10}$

\section{Algemene kenmerken}

Voordat aan de bevindingen wordt toegekomen, schetsen wij eerst twee algemene kenmerken. Ten eerste, wat

9. Een van de tien geïnterviewden was niet een slachtoffer van een ongeval, maar de ouder van een kind dat op jonge leeftijd een ongeluk heeft gehad.

10. Rijnhout e.a. 2020 , p. 25-26. betreft het type letsels in langlopende letselschadezaken ontstaat op basis van het dossieronderzoek het volgende beeld:

Ten tweede, de spreiding van de dossiers wat betreft schadejaren. Van de 201 dossiers was in drie gevallen niet bekend wat het schadejaar was. De verdeling over de jaren is als volgt:

Figuur 2 maakt duidelijk dat sprake is van aflopende curve. Het wekt geen verbazing dat de meeste zaken uit de meer recente jaren stammen. ${ }^{11}$ Het overgrote deel van de zaken wordt immers afgewikkeld binnen twee jaar, waardoor de veronderstelling gerechtvaardigd is dat de meeste resterende zaken binnen een (redelijke) periode daarna worden afgewikkeld.

\section{Verschillende redenen voor tijdsverloop}

Uit het dossieronderzoek blijkt dat dat in het grootste deel van het aantal dossiers meerdere redenen bestaan waarom een letselschadedossier na twee jaar nog steeds niet is afgewikkeld $(66 \%){ }^{12}$ Het is niet mogelijk om één dominante omstandigheid te benoemen als hét kenmerk van een langlopend letselschadedossier. Als er al één reden of omstandigheid bestaat waarom een letselschadedossier na twee jaar nog openstaat, dan betreft het een divers palet aan mogelijke omstandigheden, zo blijkt uit het dossieronderzoek. ${ }^{13}$

11. Bij het geringe aantal dossiers uit 2017 dient te worden opgemerkt dat enkel dossiers uit de eerste maanden van 2017 zijn meegenomen in het onderzoek, aangezien het onderzoek in maart 2019 gestart is.

12. Rijnhout e.a. 2020 , p. 64-65.

13. Rijnhout e.a. 2020, p. 65 . Verder werden de volgende redenen in meer of mindere mate geïdentificeerd in de onderzochte dossiers: aansprakelijkheid/onrechtmatigheid, de hoogte van de schadevergoeding of de 
Figuur 1 Aantal type letsels (n=201).Rijnhout e.a. 2020, p. 57.

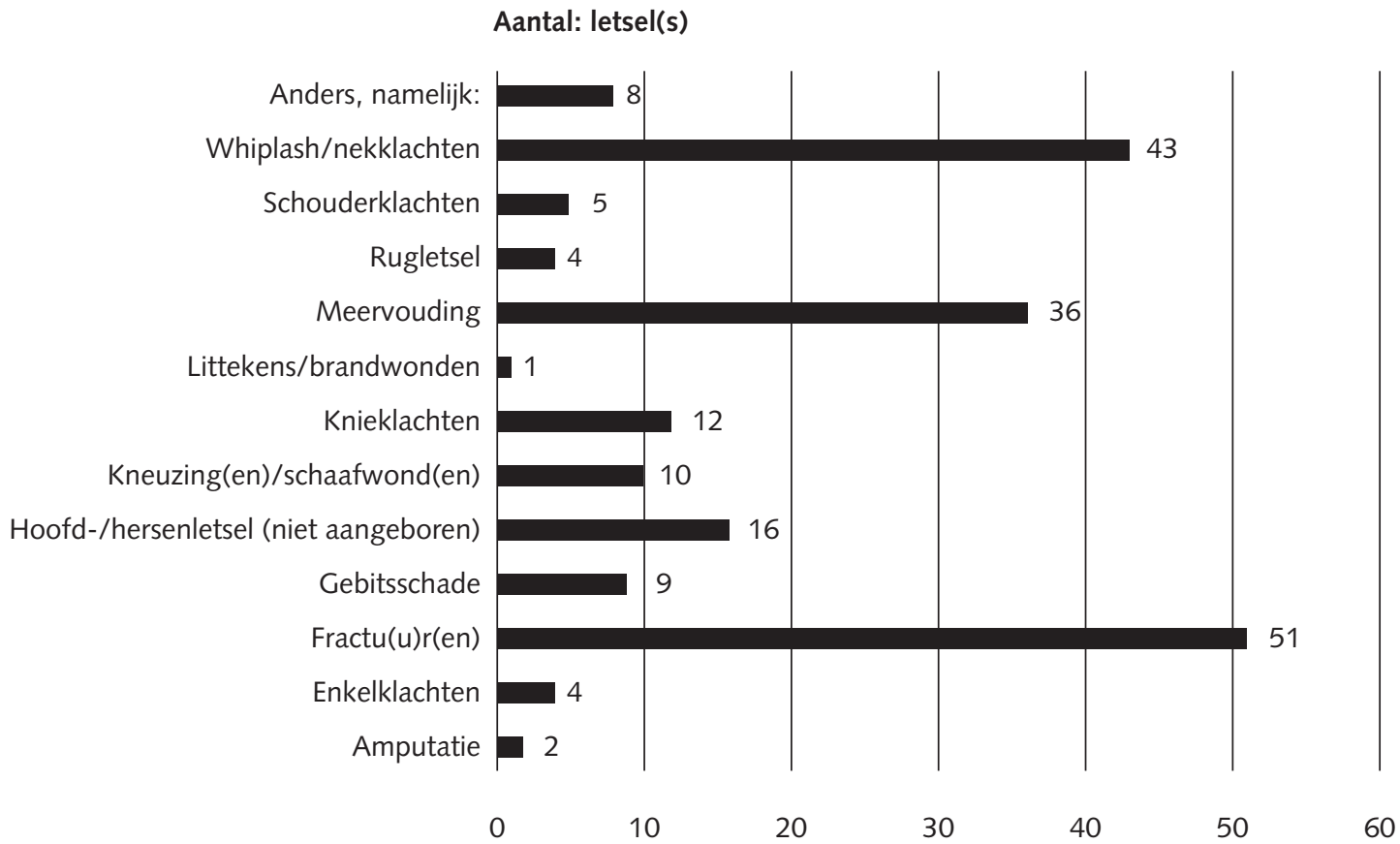

Figuur 2 Aantal dossiers per jaar van intreden van de persoonlijke schade (n=198). Rijnhout e.a. 2020, p. 59.

\section{Aantal dossiers per schadejaar}

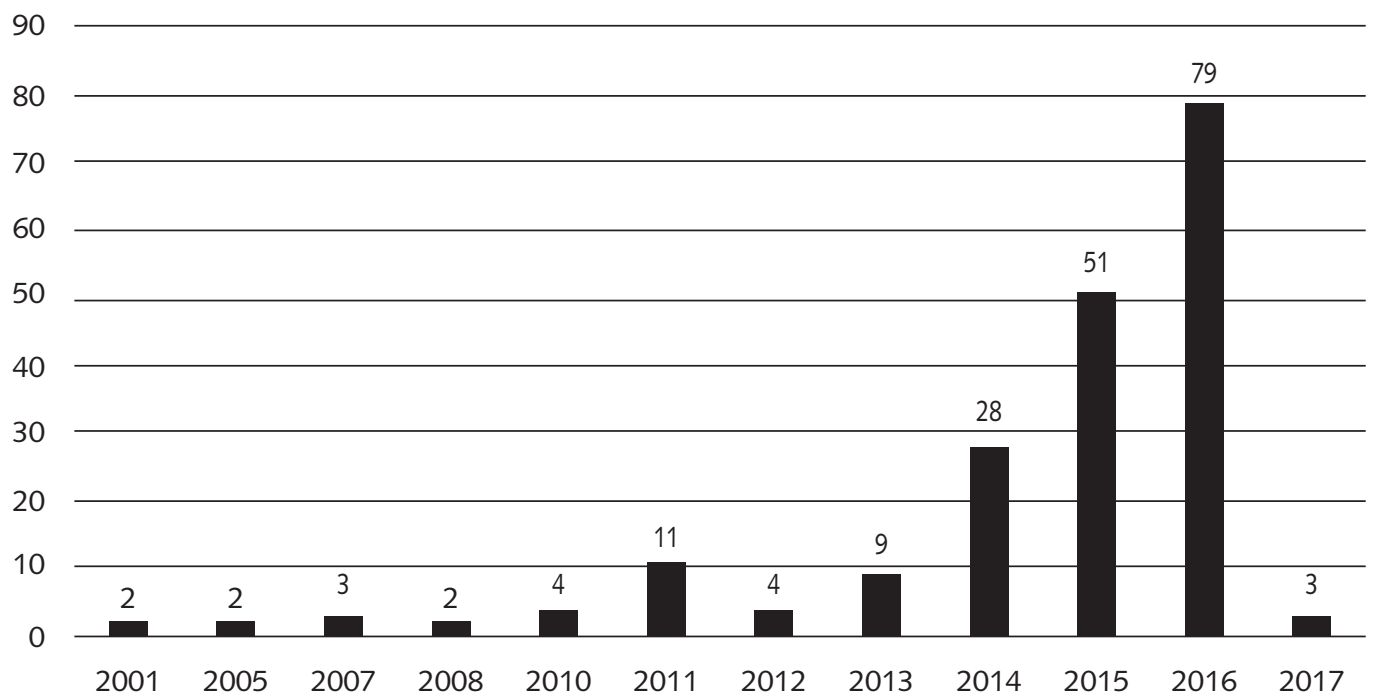

In de volgende paragrafen wordt aan de hand van drie overkoepelende thema's het tijdsverloop in letselschadezaken besproken.

\section{De materieelrechtelijke beoordeling van een letselschadevordering en tijdsverloop}

\subsection{Inleiding}

Deze paragraaf bespreekt omstandigheden die samenhangen met de materieelrechtelijke beoordeling van een letselschadevordering en die in belangrijke mate bijdragen aan tijdsverloop. ${ }^{14}$ Met die materieelrechtelijke beoordeling bedoelen wij niet alleen de juridische beoordeling van de vordering, maar ook de inhoudelijke

14. De volgende paragrafen zijn goeddeels een letterlijke weergave van het onderzoeksrapport. 
beoordeling van de medische (eind)toestand en de ongevalsgevolgen; deze zijn immers wezenlijk voor de juridische duiding en vervolgstappen.

\subsection{Medische eindtoestand}

Om tot een definitieve afwikkeling van een schadeclaim te komen moet sprake zijn van een medische eindtoestand, tenzij gebruik wordt gemaakt van een voorbehoud op dit punt. ${ }^{15}$ Verhoudingsgewijs is het ontbreken van een medische eindtoestand de vaakst voorkomende reden dat dossiers nog openstaan. Niet alleen in het dossieronderzoek en het vragenlijstonderzoek kwam deze reden valk terug, maar verhoudingsgewijs wordt het ontbreken van een medische eindtoestand minder vaak expliciet genoemd in vergelijking met het dossieronderzoek. Zoals een van de deelnemers van de focusgroep het verwoordde: 'herstel is een biologisch proces'. Ook tijdens de interviews met gedupeerden kwam dit aspect terug. Gedupeerden waarbij nog geen sprake was van een medische eindtoestand, vonden het prettig dat wordt afgewacht totdat bekend is wat de gevolgen van het ongeval precies zijn. Een aantal geïnterviewde gedupeerden ervoer pogingen van de verzekeraar om in een vroeg stadium al af te wikkelen, terwijl de (medische) gevolgen van het letsel nog onduidelijk waren, als negatief. De omstandigheid van het ontbreken van een medische eindtoestand leidt vaak tot tijdsverloop, terwijl geen enkele betrokken partij daarbij een verwijt kan worden gemaakt. Wel blijkt dat verzekeraars in deze situaties geen haast moeten maken en dat het vooral van belang is om in dergelijke gevallen 'rust te creëren', door heldere communicatie over het proces en de stand van zaken, door middel van verwachtingsmanagement bij de gedupeerde, door goede bevoorschotting en door samenwerking tussen beide partijen, aldus deelnemers van de focusgroep.

\subsection{Causaliteit}

Naast het ontbreken van de medische eindtoestand is de causaliteitsvraag een veel voorkomende reden dat een dossier nog openstaat. ${ }^{16}$ Voor de vaststelling van de ongevalsgevolgen is ten eerste medische informatie nodig over de gezondheidstoestand van de gedupeerde van (kort) voor en na het ongeval. Het verzamelen en toesturen van medische informatie lijkt echter gepaard te gaan met tijdsverloop. Het gaat in de praktijk dan niet alleen om het feitelijk verkrijgen van de informatie van verschillende instanties en de uitwisseling daarvan tussen partijen, maar ook over de vraag welke informatie moet worden verschaft aan de verzekeraar en of alle voor de beoordeling van de vordering relevante informatie is verschaft door de (belangenbehartiger van de) gedupeerde.

De vaststelling van de beperkingen kan vervolgens (en daarna pas) plaatsvinden. Allereerst zagen wij in het vragenlijstonderzoek dat - in de perceptie van de gedupeerden - tamelijk vaak een medisch deskundige is ingeschakeld. We zagen dit ook al in het dossieronderzoek: in

15. Zie hierover Rijnhout e.a. 2020, p. 170-171

16. Zie hierover Rijnhout e.a. 2020, p. 171-173 vrijwel alle zaken is een of meerdere medisch adviseurs actief en in bijna de helft van de zaken is (reeds) een medische expertise benut, met name voor de vaststelling van de beperkingen. Dat is relevant, omdat uit het onderzoek ook blijkt dat de uitvoering van een medische expertise gepaard gaat met (fors) tijdsverloop. Ook worden diverse 'medische kwesties' (wat een breder begrip is dan het vaststellen van beperkingen) door gedupeerden het vaakst genoemd als reden dat hun dossier nog niet is afgewikkeld.

Niet alleen moeten de beperkingen worden vastgesteld, ook moet vast komen te staan dat die zijn veroorzaakt door het ongeval. Causaliteit is immers een van de juridische criteria om de verantwoordelijkheid voor de schade te verschuiven van de gedupeerde zelf naar de aansprakelijke partij (en meestal: zijn aansprakelijkheidsverzekeraar). Wat wij in het dossieronderzoek hebben gezien, is dat discussie over causaliteit in bijna een kwart van de dossiers een van de redenen is dat het dossier nog openstaat, waarvan de helft dossiers zijn waarin de gedupeerde whiplash/nekklachten heeft. Causaliteit is in ongeveer een vergelijkbaar deel van de respons in het vragenlijstonderzoek de belangrijkste discussie volgens gedupeerden. Uit de interviews leren wij dat het door gedupeerden als negatief wordt ervaren dat de aansprakelijkheidsverzekeraar bereid is om veel energie te steken in en kosten te maken voor medisch onderzoek naar eventuele pre-existentie, terwijl daar in de ogen van een aantal gedupeerden geen sprake van was.

\subsection{Hoogte van de vergoeding}

Een andere reden die veel werd gevonden, was de hoogte van de schadevergoeding. ${ }^{17}$ In zowel het dossieronderzoek als het vragenlijstonderzoek zagen wij het verlies van arbeidsvermogen als belangrijkste discussiepunt terugkomen, zowel ten aanzien van vragen over re-integratie als over de vergelijking tussen de situatie waarin de gedupeerde zou hebben verkeerd zonder het ongeval en de situatie zoals die is ontstaan met en na het ongeval. Onzekerheden over zowel de re-integratie, scholing, de voortzetting van een onderneming en de inkomsten die zouden zijn vergaard als het ongeval niet zou hebben plaatsgehad als het ontbreken van een medische eindtoestand en duidelijkheid over de belastbaarheid spelen daarbij een rol. Aandacht voor deze schadepost is belangrijk, omdat het geregeld een groot deel van de schadevergoeding betreft. Bovendien blijkt uit het vragenlijstonderzoek dat 'als ik krijg wat ik nodig heb om te leven met mijn letsel' een belangrijke reden is voor gedupeerden om het schadevergoedingsaanbod van de verzekeraar te accepteren. ${ }^{18}$

Een andere discussie die wij in beide onderdelen van het onderzoek zagen terugkomen, is de discussie over huis-

17. Zie hierover Rijnhout e.a. 2020, p.173-174.

18. Dit lijkt een bevestiging van M.E. Huver et al., Slachtoffers en aansprakelijkheid. Een onderzoek naar behoeften, verwachtingen en ervaringen van slachtoffers en hun naasten met betrekking tot het civiele aansprakelijkheidsrecht. Deel 1: Terreinverkenning, Den Haag: WODC 2007, p. 81-82 (financiële bestaanszekerheid). 
houdelijke hulp. De discussie spitst zich volgens deelnemers van de focusgroep toe op de tarieven, de behoefte en de hoeveelheid uren per zorgtaak. Hoewel er een richtlijn van De Letselschade Raad bestaat over huishoudelijke hulp (die echter geldt voor de eerste drie tot zes maanden na het ongeval), is discussie hierover in langlopende letselschadedossiers relatief veel voorkomend.

Verder is opvallend dat meer dan de helft van de gedupeerden aangeeft dat het meest wordt gediscussieerd over smartengeld. Die indruk wordt niet bevestigd in het dossieronderzoek. Om die reden is daarop doorgevraagd in de focusgroepen. Uit de schriftelijke ronde van de focusgroep kwam een eenduidig beeld naar voren: het overgrote deel van de deelnemers herkende niet dat discussie over smartengeld zorgt voor vertraging.

\subsection{Re-integratie}

Voor de materiaalrechtelijke afwikkeling van een letselschadedossier is de re-integratie een belangrijk thema. ${ }^{19}$ Gedupeerden noemen deze reden zelf niet als mogelijke reden voor tijdsverloop, maar als gevraagd wordt naar de discussie over schadeposten worden het verlies van arbeidsvermogen en re-integratie wel regelmatig genoemd als bronnen van discussie. Net zoals bij de medische eindtoestand is tijdsverloop door re-integratie soms onoverkomelijk. Ook hier is volgens de focusgroep voor het slachtoffer van belang dat in het dossier rust wordt gecreëerd.

\subsection{Belasting van de materieelrechtelijke discussies}

Een laatste uitkomst die betrekking heeft op de materieelrechtelijke beoordeling van de schadevordering heeft te maken met de bewijspositie van partijen. ${ }^{20}$ Zowel in de interviews als in het vragenlijstonderzoek blijkt dat gedupeerden het belastend vinden dat zij verantwoording moeten afleggen aan de verzekeraar over de gevraagde voorschotten en het letsel. In de interviews gaven meerdere gedupeerden aan dat zij dit zeer belastend vinden in de situatie waarbij het voor gedupeerden zelf duidelijk is wat de hoogte van een schadebedrag of voorschot zou moeten zijn. Gedupeerden gaven ook aan het belastend te vinden wanneer de aansprakelijkheidsverzekeraar medische rapporten in twijfel trekken. Dit punt verdient nader onderzoek, maar wordt ook al wel genoemd in andere wetenschappelijke literatuur op basis van empirisch onderzoek ${ }^{21}$ of ervaring, ${ }^{22}$ en is (als

19. Zie hierover Rijnhout e.a. 2020, p. 173.

20. Zie hierover Rijnhout e.a. 2020, p. 174-175.

21. A.J. Akkermans, 'Achieving Justice in Personal Injury Compensation: The Need to Address the Emotional Dimensions of Suffering a Wrong', in: P. Vines \& A.J. Akkermans (eds.), Unexpected Consequences of Compensation Law, Oxford: Hart Publishing 2020, p. 15-37 (met name paragraaf V-F). Reeds daarvoor: Huver e.a. 2007, p. 67-68.

22. G.M. van Wassenaer, 'Mediation Dé oplossing in letselschadezaken?', VR 2016, p. 49-56; L. Charlier, 'Mediation in letselschade blijft ten onrechte achter', L\&S 2018/3, p. 16-24; E.W. Bosch, 'Letselschade: mag het een onsje minder belastend', AA 2020, p. 353-357. gezegd) bevestigd gedurende de focusgroepen in dit onderzoek.

\section{De processuele afwikkeling van een letselschade- vordering en omstandigheden die zorgen voor tijdsverloop}

\subsection{Inleiding}

Naast de (juridisch) inhoudelijke beoordeling van de vordering is in het onderzoek ook aandacht uitgegaan naar de processuele aspecten van de vordering. ${ }^{23}$ Het gaat dan om het afwikkelingsproces zelf: welke stappen worden gezet en welke niet, en hoe draagt dat bij aan tijdsverloop? Een aantal aspecten van het afwikkelingsproces blijkt van invloed te zijn op (de perceptie van) tijdsverloop in een letselschadedossier.

\subsection{Vele partijen betrokken bij afwikkeling}

Een van die aspecten is de hoeveelheid aan partijen die betrokken zijn bij de afhandeling van een dossier. ${ }^{24}$ Een aantal geinterviewde slachtoffers spreekt over de vele 'schakels' en 'lijntjes' in het proces. Naast de gedupeerde, diens belangenbehartiger en de (dossierbehandelaar van de) aansprakelijkheidsverzekeraar kunnen ook de medisch adviseur van de belangenbehartiger of gedupeerde, de externe schadebehandelaar van de aansprakelijkheidsverzekeraar, de medisch adviseur van de verzekeraar, de artsen die een medisch expertise doen en in sommige gevallen de rechter of mediator betrokken zijn bij het afwikkelingsproces. Naast deze verschillende betrokkenen kunnen ook nog medisch hulpverleners, herstelcoaches, arbeidsdeskundigen, andere verzekeraars of bijvoorbeeld het UWV bij de afwikkeling van de schade betrokken zijn. Al met al een grote hoeveelheid betrokkenen, die niet altijd direct contact met elkaar hebben. In zowel het dossieronderzoek, het vragenlijstonderzoek, de focusgroep als de interviews zien wij dat deze hoeveelheid betrokkenen en verschillende 'lagen' kunnen leiden tot tijdsverloop. Dit komt bijvoorbeeld doordat betrokken partijen soms op elkaar moeten wachten voordat een volgende stap in het proces genomen kan worden, terwijl ook duidelijk is geworden dat de werkdruk bij veel partijen groot is en dat bij specialistische artsen soms sprake is van wachttijden. In de interviews hoorden we regelmatig dat gedupeerden zich afvragen waarom er zo veel 'schakels' en 'lijntjes' moeten zijn.

De Gedragscode Behandeling Letselschde voorziet al wel in mogelijkheden voor direct contact, zoals het opstellen van het behandelplan, het driegesprek en de

23. Ook de volgende delen zijn een vrijwel letterlijke weergave van het onderzoeksrapport

24. Zie hierover Rijnhout e.a. 2020, p. 175-177 
gezamenlijke tweejaarsevaluatie, maar het valt te betwijfelen of dit voldoende effectief is. Uit het dossieronderzoek blijkt in ieder geval dat de gezamenlijke tweejaarsevaluatie in de meeste gevallen wordt gedaan door de aansprakelijkheidsverzekeraar volgens het vier-ogenprincipe, waarbij het verkregen beeld niet nog wordt afgestemd met de wederpartij. ${ }^{25}$ Als het gaat over medisch advies, is relevant dat De Letselschade Raad de 'Aanbeveling werken met één medisch adviseur' heeft ontwikkeld in 2018; wij zie het gebruik van een gezamenlijke medisch adviseur slechts in twee dossiers terug.

\subsection{Medisch beoordelingstraject}

Het medisch beoordelingstraject is ook in een groot aantal gevallen een oorzaak van tijdsverloop. ${ }^{26}$ In het grote merendeel van de onderzochte dossiers hebben partijen beide een eigen medisch adviseur ingeschakeld. Het verzamelen en uitwisselen van medische informatie zorgt voor tijdsverloop. Volgens de focusgroep gaat de totstandkoming en uitwisseling van medische adviezen vaak gepaard met tijdsverloop, omdat het tempo waarin dit plaatsvindt gering is. Ook de medische expertise is in veel gevallen een belangrijke oorzaak van tijdsverloop, omdat de overeenstemming over de uitvoerend specialist en de vraagstelling, het daadwerkelijk uitvoeren van de expertise en de discussie na afloop van de expertise tijd kosten. Ook is het aspect van wachtlijsten genoemd.

\subsection{Gering beroep op de rechter of mediator}

In de dossiers die in het onderzoek zaten, is slechts in vijf gevallen een beroep gedaan op de rechter. ${ }^{27}$ Dat beeld is op zich in lijn met het grotere beeld dat bestaat over het aantal zaken waarin een beroep wordt gedaan op de rechter. Wat wel duidelijk lijkt te worden, is dat de rechter de 'oudere' langlopende letselschadedossiers voorgelegd krijgt. Daarmee rijst de vraag - maar dat hebben wij niet onderzocht - of een beroep op de rechter in een vroeger stadium leidt tot een vlottere afwikkeling. Een vergelijkbare vraag rijst in het kader van mediation. Slechts in vier zaken is een beroep gedaan op een mediator en dat waren ook met name zaken met een schadedatum van voor 2012.

\section{Het handelen van partijen: omstandigheden die bijdragen aan tijdsverloop}

\subsection{Inleiding}

In het laatste deel staan de positie en het handelen van partijen in langlopende letselschadezaken centraal. ${ }^{28}$

25. Of een gezamenlijk evaluatie zou leiden tot minder tijdsverloop is overigens niet nader onderzocht.

26. Zie hierover Rijnhout e.a. 2020, p. 177

27. Zie hierover Rijnhout e.a. 2020, p. 178

28. Ook deze paragraaf is letterlijk terug te vinden in het onderzoeksrapport.
Hier staat dus niet de inhoud van de vordering of het proces ter beoordeling daartoe centraal, maar de verschillende posities en het handelen van professionals in de letselschadebranche. Met professionals bedoelen wij hier alleen de dossierbehandelaars bij aansprakelijkheidsverzekeraars en belangenbehartigers van gedupeerden.

\subsection{Niet-tijdig communiceren en gepercipieerde} voortvarendheid

Uit het dossieronderzoek blijkt dat niet-tijdig communiceren in een deel van de bestudeerde dossiers een reden was voor tijdsverloop. ${ }^{29}$ In $8 \%$ van de dossiers werd door de dossierbehandelaar van de aansprakelijkheidsverzekeraar niet tijdig gecommuniceerd en in 14\% was dit door de belangenbehartiger van de gedupeerde. In het vragenlijstonderzoek en in de interviews is stilgestaan bij hoe gedupeerden de voortvarendheid, of het gebrek daaraan, percipieerden. ${ }^{30}$ Uit het vragenlijstonderzoek blijkt dat gedupeerden de voortvarendheid van de dossierbehandelaar beneden neutraal beoordelen (1.99 $(s d=1.086$, bij $\mathrm{n}=173)$, op een schaal van 1 (Geheel niet voortvarend) tot 5 (Zeer voortvarend)) en dat zij de voortvarendheid van belangenbehartigers positiever beoordeelden $(3.43(s d=1.11$ bij $\mathrm{n}=161))$. Voortvarendheid lijkt dus iets anders te zijn dan niet-tijdig communiceren. Hoe dit komt, is niet helemaal zeker, maar het vermoeden bestaat dat ervaren procedurele rechtvaardigheid door de gedupeerde hier een rol speelt en dat gedupeerden steeds weer verantwoording moeten afleggen over de (hoogte van) schadevergoeding en/of het letsel. Bij ervaren procedurele rechtvaardigheid gaat het dus om elementen als voice, de neutraliteit van de beslissende autoriteit, de motieven van de beslissende autoriteit, uitleg en een rechtvaardige, beleefde en respectvolle behandeling. ${ }^{31}$

Wij leiden dat vermoeden af uit het volgende. Hoewel de gemiddeld hoogste score op de vraag (in de vragenlijst) in hoeverre een bepaalde omstandigheid een belangrijke rol zou spelen om het schadevergoedingsaanbod van de verzekeraar te accepteren, gegeven is op de stelling 'Als ik zou krijgen wat ik nodig heb om te leven met mijn letsel' (gem. 4.31 op een schaal van 1-5, met $s d=0.97$ ), volgen daarna twee omstandigheden die betrekking hebben op ervaren procedurele rechtvaardigheid. Als één na hoogste scoorde immers 'Als mijn financiële schade soepeler/vlotter zou worden afgewikkeld' (gem. 4.11, met $s d=1.09$ ), en daarna 'Als ik meer invloed zou hebben op het proces van afwikkeling van mijn vordering' (gem. 3.89, $s d=1.06$ ). $\mathrm{Nu}$ is het zo dat de respondenten die deze vragenlijst hebben ingevuld, personen zijn wier dossier nog openstaat. Wij moeten derhalve voorzichtig zijn met gevolgtrekkingen hieruit,

29. Zie hierover Rijnhout e.a. 2020, p. 178-179

30. Zie hierover Rijnhout e.a. 2020, p. 181-183

31. Zie p. 35-37 van het online onderzoeksrapport voor meer informatie en vindplaatsen. Hierbij benadrukken wij dat dit onderzoek niet zag op ervaren procedurele rechtvaardigheid op zich. Wij zagen elementen daarvan terug in het vragenlijstonderzoek en de interviews. Wij kunnen dus niet vaststellen welk element dominant is in langlopende letselschadezaken. 
juist omdat zij nog niet definitief hebben afgewikkeld en dus onbekend is wat hen uiteindelijk zal motiveren om inderdaad een voorstel te accepteren. Desalniettemin laten de cijfers zien dat het proces en de mate waarin dat als rechtvaardig wordt ervaren, ook belangrijk zijn, of in ieder geval kunnen zijn, voor de acceptatie van een schadevergoedingsaanbod. ${ }^{32}$ Dat procedurele rechtvaardigheid belangrijk is, ook hier, laten ook de antwoorden op de daarna volgende vraag in het vragenlijstonderzoek zien. Die vraag ging over wat er aan het proces van afwikkeling veranderd kan worden zodat op korte termijn kan worden afgewikkeld. Wij vertelden daarover eerder al. Het vaakst werd genoemd 'Niets/weet ik niet' en daarna 'betere communicatie en overleg', en vlak daarna 'het door de verzekeraar nemen van verantwoordelijkheid en sneller reageren' en 'serieus nemen klachten en begrip tonen'. 'Betere communicatie en overleg' kan uiteraard betrekking hebben op zowel de aansprakelijkheidsverzekeraar als de eigen belangenbehartiger; in elk geval wordt zo duidelijk dat deze elementen van procedurele rechtvaardigheid door een deel van de gedupeerden als belangrijk worden ervaren. Dat lijkt ook voort te vloeien uit opmerkingen van twee deelnemers aan de focusgroep; zij zijn kritisch over de toonzetting en het taalgebruik in medische adviezen. $\mathrm{Zij}$ stellen dat deze zelfs contraproductief kunnen werken voor de afwikkeling, vanwege de frustratie, de boosheid en het gebrek aan erkenning die deze dan oproepen. Dat bevestigt een vermoeden dat respectvolle bejegening kan samenhangen met extra tijdsverloop. Een meer empathische (respectvolle) insteek/houding van de dossierbehandelaar wordt door veel gedupeerden als belangrijke aanbeveling genoemd in de interviews. Niet onwaarschijnlijk is dat die aanbeveling evenzeer geldt voor de belangenbehartiger van de gedupeerde. ${ }^{33}$

Een belangwekkend punt, hoewel dat niet altijd en direct hoeft samen te hangen met tijdsverloop, is dat een kwart van de gedupeerden in het vragenlijstonderzoek (26\% bij $n=163)$ het idee heeft dat zij onvoldoende op de hoogte zijn van de stand van zaken in hun dossier. ${ }^{34}$ Van deze respondenten geeft ongeveer een derde aan dat zij meer willen weten over die stand van zaken (de procedure en de voortgang daarvan). Dit beeld strookt met wat wij in de interviews hebben gehoord: gedupeerden wisten heel goed wat de (juridische) discussiepunten waren, maar hadden behoefte aan meer contact over de voortgang en inzicht in de uitvoering van het werk. ${ }^{35}$ Ook de deelnemers aan de focusgroepen benadrukken het belang van duidelijker communicatie over het proces (en ook: de lengte van bepaalde beoordelingsprocessen daarbinnen) en de stand van zaken. $\mathrm{Zij}$ vinden het ook belangrijk dat de verwachtingen van de gedupeerde goed worden gemanaged.

\footnotetext{
Zie hierover Rijnhout e.a. 2020, p. 183-184

Zie immers Elbers, Van Wees \& Akkermans, TVP 2012, p. 113.

Zie hierover Rijnhout e.a. 2020, p. 182-183.

Zie ook Huver e.a. 2007, p. 88
}

\subsection{Wisselingen op dossierniveau}

Naast het niet-tijdig communiceren door de dossierbehandelaar of de belangenbehartiger zijn de wisselingen op dossierniveau door de aansprakelijkheidsverzekeraar en door de gedupeerde vaak gezien. ${ }^{36}$ In bijna de helft van de onderzochte dossiers is gewisseld van dossierbehandelaar door de aansprakelijkheidsverzekeraar. Uit het dossieronderzoek bleek echter dat maar in een gering aantal dossiers een wisseling van de dossierbehandelaar de reden was dat het dossier nog niet was afgewikkeld. In de interviews is aan gedupeerden gevraagd naar de impact die een wisseling heeft op het proces. In de perceptie van een aantal geïnterviewde gedupeerde werd door een wisseling van dossierbehandelaar tijdsverloop veroorzaakt. Hoewel in de focusgroep werd aangegeven dat een wisseling een positieve invloed kan hebben op de afwikkeling van het dossier, ontstond het beeld tijdens de interviews dat wisselingen veel irritatie en onbegrip kunnen opleveren, bijvoorbeeld omdat een gedupeerde aan een dossierbehandelaar op huisbezoek voor de zoveelste keer de situatie moest uitleggen. Uit het dossieronderzoek blijkt dat ongeveer een derde van de gedupeerden van belangenbehartiger wisselt. De belangrijkste reden daarvoor lijkt dat de belangenbehartiger in de ogen van de gedupeerde slechte kwaliteit levert, gevolgd door moeilijkheden met communicatie.

\section{Drie reflecties}

Ons is niet de opdracht gegeven om specifieke aanbevelingen voor verbetering (lees: versnelling) aan te reiken. In deze discussieparagraaf beperken wij ons dus tot enkele reflecties op de onderzoeksresultaten. ${ }^{37}$

Onze eerste reflectie betreft het veelzijdige en ingewikkelde beeld van de kenmerken en potentiële redenen voor tijdsverloop in letselschadezaken dat is ontstaan, verstevigd en bestendigd gedurende het onderzoek. Zeker naar aanleiding van de gesprekken tijdens de focusgroepen en op basis van het dossieronderzoek bij dertien aansprakelijkheidsverzekeraars, is het voor ons zeer duidelijk geworden dat langlopende letselschadezaken (WAM, AVP, AVB) veelal openstaan vanwege onvermijdelijke en niemand na te dragen redenen (zoals afwachten van de medische eindtoestand van de gedupeerde, de re-integratie in het arbeidsproces en de onduidelijkheid over de door het ongeval veroorzaakte beperkingen). Het over en weer 'de ander' verantwoordelijk houden voor extra tijdsverloop is, gegeven de karakteristieken van letselschadezaken, geen houdbaar standpunt. Dat het afwikkelingssysteem als zodanig door gedupeerden wel als belastend wordt ervaren, wordt duidelijk uit de interviews met gedupeerden en uit de focusgroepen met professionals uit de letselschadebranche, waarbij het vragenlijstonderzoek onder

36. Zie hierover Rijnhout e.a. 2020, p. 180-181

37. Deze reflecties zijn vrijwel letterlijk terug te vinden op Rijnhout e.a. 2020, p. 184-185. 
gedupeerden een belangrijke inkijk geeft in waarom dat zo is. Met name het als slachtoffer steeds weer verantwoording moeten afleggen over het letsel en over de schade wordt als belastend getypeerd. Dat afwikkelingssysteem is echter een (wettelijk) gegeven waarbinnen de professionals in de branche moeten werken. Bij die onvermijdelijkheid past wel de oproep van de deelnemers aan de focusgroepen dat het belangrijk is om 'rust te creëren' in een langlopend letselschadedossier door heldere communicatie over het proces, de stand van zaken en de (juridische) inhoud, door middel van verwachtingsmanagement bij de gedupeerde, door goede bevoorschotting (bij voorkeur gelabeld en voorafgegaan door een goed onderbouwde schadestaat) en door - wat wij dan noemen - samenwerking (gezamenlijk en met empathie zoeken - eventueel met een coach - naar een oplossing voor de gedupeerde).

Een tweede reflectie is dat er veel partijen betrokken zijn en dat de verschillende partijen soms maar weinig direct contact hebben met elkaar. Wat wij ook zagen en hoorden is dat partijen op elkaar moeten 'wachten'. Een en ander kan goed verklaarbaar zijn vanwege het (complexe) systeem (waarin partijen informatie, standpunten of vorderingen niet willen 'prijsgeven'), maar bedacht moet worden - zoals uit de interviews bleek - dat in elk geval de gedupeerden die wij hebben gesproken meenden dat het beter zou zijn als er minder 'lijntjes' zouden bestaan.

Een derde reflectie is dat ons onderzoek regelmatig niet meer (alleen) ging over tijdsverloop en de kenmerken daarvan, maar ook over (wat wij noemen) de kwaliteit van de schaderegeling, over (on)tevredenheid en over relaties. Hoewel de medische eindtoestand, discussies over de hoogte van de schade (met name het verlies van arbeidsvermogen/verdienvermogen) en causaliteit in het dossieronderzoek pregnant naar voren kwamen als redenen dat dossiers nog openstaan, kwam door het vragenlijstonderzoek, de interviews en de focusgroepen verhoudingsgewijs ook meer nadruk te liggen op de kwaliteit van communicatie door professionals in de branche, op deskundigheid van professionals, op een respectvolle en empathische insteek jegens de gedupeerde, op onderling vertrouwen en op het belang van goede samenwerking tussen professionals (bijvoorbeeld door (samen) te zorgen voor adequate bevoorschotting). De wijze waarop de professionals in de branche zich opstellen ten opzichte van elkaar én ten opzichte van de gedupeerde, lijkt erg belangrijk, zeker als bij voorbaat al duidelijk is dat er onvermijdelijk tijdsverloop zal optreden door de kenmerken van de zaak.

Het voorgaande is wellicht mede ingegeven en verklaarbaar door de gekozen onderzoeksmethode (combinatie van dossieronderzoek en perceptieonderzoek), maar wij kunnen ons niet aan de indruk onttrekken dat de vraag naar de (snelheid van) afwikkeling meerdere lagen heeft. Meerdere omstandigheden werken onderling als communicerende vaten: de juridische discussie, het proces, en de samenwerking en communicatie. Gedupeerden lijken het systeem waarin wordt gewerkt en ook de wijze waarop daarin wordt gewerkt, niet (altijd) te waarderen en dat slaat naar verwachting ook terug op het tijdsverloop. Dit alles kan wellicht gedeeltelijk worden ondervangen door veranderingen binnen het systeem (aanpassing van het juridisch systeem) en binnen de organisatorische context (aanpassing van informatievoorziening, gewoonten, processen etc.) (maar daarover gaat ons onderzoek niet), maar het vraagt ook om veranderingen die zien op de persoonlijkheid van de individuele dossierbehandelaar, de individuele belangenbehartiger en alle andere individuen die een rol spelen in een letselschadezaak: het gaat ook om de bereidheid van een ieder om goed samen te werken op basis van vertrouwen en met empathie. 